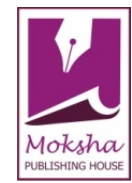

\author{
Review Article \\ www.ijrap.net
}

\title{
CRITICAL ANALYSIS OF CONCEPT OF PRAKRITI AND CHALLENGES IN ITS ASSESSMENT: A REVIEW \\ Tripathi Piyush Kumar ${ }^{1 *}$, Gehlot Sangeeta ${ }^{2}$ \\ ${ }^{1}$ Ph.D Scholar, Department of Kriya Sharir, Faculty of Ayurveda, Institute of Medical Sciences, Banaras Hindu University, Banaras, UP, India \\ ${ }^{2}$ Professor \& Head, Department of Kriya Sharir, Faculty of Ayurveda, Institute of Medical Sciences, Banaras Hindu University Banaras, UP, India
}

Received on: 16/04/16 Revised on: 25/05/16 Accepted on: 03/06/16

\begin{abstract}
*Corresponding author
E-mail: dr.piyushtripathi@gmail.com
\end{abstract}

DOI: 10.7897/2277-4343.07399

\begin{abstract}
Ayurveda is one of the oldest health sciences of the world with concepts of Tridosha and Prakriti (Ayurvedic constitution)being core philosophies.Unique concept of Prakriti makes this pathy a step forward towards personalized approach of treatment.In Ayurveda,the physician's bimodal approach of clinical examination (disease diagnosis and patient diagnosis) is used to determine the root cause of the disease and to determine the mode of treatment selection. Prakriti assessment becomes very crucial in this personalized approach but Prakriti assessment result of same individuals is not unanimous all the time, that shows poor reliability results. Tools used for Prakriti assessment i.e. Prakriti assessment proformas itself have so many challenges.We emphasize the use of an objectively defined questionnaire and software analysis in establishing a Prakriti assessment, a method which yields more reliable results.
\end{abstract}

Keywords: Prakriti assessment, Ayurvedic constitution, Prakriti.

\section{INTRODUCTION}

Ayurveda is the ancient medical science prevalent for thousands of years in the Indian subcontinent.One of the key fundamental theories of Ayurveda involves a system of understanding health and disease known as the Tridosha. The ancient texts of Ayurveda mention numerous properties of Doshas (Vata,Pitta and Kapha) and how they affect a human being's physiology or Prakriti (Psychosomatic constitution)based on the dominance of one or more Doshas.The Prakriti or the Ayurvedic constitutional type of an individual is fixed at conception and is articulated through physical, psychological, immunological, and behavioural traits as described elaborately in original Ayurvedic texts.The Prakriti of a person is quite capable of providing a fair indication of physiological strengths and weaknesses, mental tendencies, and susceptibility to illnesses of various types ${ }^{1}$.

Such a classification of individuals based on body temperament by deciphering specific phenotypic characters for health management is not confined up to Ayurveda only.Such traditional classification systems for personalized medicine are widely used in many countries in the form of naturopathic medical systems of body type in the America and Europe, constitutional medicine in China,Ikkando medicine in Japan and Sasang typology in Korea also. ${ }^{2,3,4,5}$ These contemporary traditional systems of medical classification consider the person as a whole, rather than focusing on particular organ or biological systems as done in allopathic medicine in the west.

\section{Prakriti: the basis of personalized medicine}

Uniqueness of Ayurveda comes into form of Prakriti i.e. once his/her individual constitution is detected then we can be able to prevent and cure the disease stage by managing the diet and behavioural regimen according to individual constitution and predominant Dosha. This concept of Prakriti has remained a subject of extensive exploration in the recent past. As a result, it is now better understood in terms of its genomic and biochemical correlations and subsequent clinical applications. ${ }^{7-}$ 10

Since innate disposition determines the manifestation of diseases and individual response to treatment, one of the first things a physician does is to determine the Prakriti of his patient. The description of the features clearly suggests that the innate dispositions or Dosha Prakritis represent phenotypes. This is necessary to personalize treatment in accordance with the basic principle of Ayurvedic therapeutics. ${ }^{11}$ So Ayurvedic system of medicine have a personalized approach in treating a patient with centuries of practice, rightly called experiential science. ${ }^{12,13}$

\section{Concept and importance of Prakriti}

So concept of Prakriti finds a base role on which whole skeleton of personalized medicine is framed. Prakriti assessment is a part of Dashavidha Atur Pariksha ${ }^{14}$ (Ten points investigation of patient) and is considered in totality with understanding of other minimum nine aspects. If the constitution is known then herbs, diet and other regimens including yogic postures can be advised correctly both for disease treatment and to promote longevity.

Schools of thought regarding concept of Prakriti and its formation

There are two schools of thought,

a- Thoughts related to School of Surgery.

b- Thoughts related to School of Medicine

a-Thoughts related to School of Surgery- Acharya Sushruta and his followers belong to school of surgery i.e. surgeons. In most of the instances medical cases that are dealt by surgeons 
are almost Atyayik (emergency) cases means they have not much time to think about the Prakriti of patients.In Atyayik situation one has to make sure about saving patients life rather assessing Prakriti of patient and planning treatment according to the same, so school of surgery simply stresses on the physiological predominance of Dosha in Shukra and Shonita ${ }^{15}$.

b-Thoughts related to School of Medicine - Acharya Charak and his followers belong to school of medicine. They follow the principle "Swasthasya Swasthya Rakshanam Aturasya Vikar Prashamanam Cha" means their primary vision is the maintenance of health followed by cure of diseases.Prevention of the disease and maintenance of health can be achieved by planning the diet and behavioural regimen according to Prakriti.

Acharya Charak considers four major embryonic factors that decide the Prakriti of an individual.

1-Shukra Shonita Prakriti (Nature of sperm and ovum)

2- Kaal -Garbhashaya Prakriti (Nature of womb)

3-Matur Ahara Vihara Prakriti (Diet and behavioural regimen followed by mother)

4-Panchamahabhutavikara Prakriti (Predominance of five basic elements) ${ }^{16}$.

Acharya Charak has considered that post embryonic factors also affect the Prakriti of individual i.e.

1.Jatiprasakta (Racial peculiarities)

2.Kulaprasakta (Familial predisposition)

3. Deshanupatini (Demographic)

4.Kalanupatini(Seasonal effect)

5.Vayonupatini (Natural changes according to age)

6.Pratyatmaniyata (Personal habits \& individuality, Idiosyncrasy). ${ }^{17}$

\section{Challenges}

Understanding of Prakriti and its assessment becomes crucial but assessment of Prakriti has not remained a unanimous result most of the times.In Ayurveda, diagnostic methods(such as Prakriti assessment, pulse diagnosis etc.)often rely on some degree of subjective interpretation by physicians. We find that if Prakriti of same individual is assessed by different physicians there is difference of opinion regarding same.

In a study Kurande V.et al.(2013) assessed the inter-rater reliability of Ayurvedic pulse (nadi), tongue (jivha), and body constitution (Prakriti) assessments. Fifteen registered Ayurvedic doctors with 3-15 years of experience independently examined twenty healthy subjects. Kappa statistics for all 105 pairs of doctors were computed for the pulse, tongue, and Prakriti data sets. The average pair wise kappa for pulse, tongue, and Prakriti was $0.07,0.17$, and 0.28 , respectively. Thus, the results demonstrate a low level of reliability for all types of assessment made by doctors. ${ }^{18}$

Reliability studies in Ayurveda are in the preliminary stage so it is a crucial issue in classification (such as Prakriti classification), method development (pulse diagnosis), quality assurance for diagnosis and treatment and in the conduct of clinical studies. ${ }^{19}$

\section{Problems associated with Prakriti and its assessment}

There are theoretical and practical problems associated with Prakriti assessment.

1-Theoretical problems related to Prakriti-Acharya Charak considers that mere physiological predominance of Dosha in Shukra and Shonita does not decide the Prakriti of an individual.
Along with these, predominance of Mahabhoota, diet and behavioural regimen of mother, nature of womb and Kaal also decide the Prakriti.He has further added that some other factors like personal habits etc. also have influence the Prakriti of an individual means he indicates that Prakriti formation is dependent on a number of factors but when we prepare the Prakriti assessment questionnaire/proforma then we do not incorporate the post embryonic factors that may affect the Prakriti e.g. Pratyatmaniyata (personal habbit).

Acharya Charak describes that predominant manasika guna of an individual can be changed by continuous practice of certain mansika gunas or thoughts. So once there is alteration in the configuration of mansika guna, this will affect the sharirika guna that will ultimately alter the Panchamahabhoota configuration in the body. So we can say that this alteration will be having an effect on Prakriti but it is not considered often.

2-Practical Problems related to Prakriti assessmentWhenever we assess the Prakriti in large scale,we generally use Prakriti assessment proforma/questionnaire. We find too many questionnaires available for assessing the Prakriti but no questionnaire is exactly similar with another of its kind e.g.

(i)-The questionnaires available are of the following types depending on who assessed the Prakriti:

a-The questionnaires that required interrogation and clinical examination of the individual to be carried out by the physician. b-The questionnaire that were of self- assessment type, where subjects themselves would fill up the questionnaire, and would decide their Prakriti.

Each method has its own merits and demerits. It becomes difficult to judge which method is better because in physician based questionnaire sometimes it becomes difficult to judge subjective parameters related to individuals e.g. appetite, bowel habit, memory, anger and sometimes individuals may hide their personal information e.g. if they are greedy, jealousness, their sexual feeling and behaviour etc.

In self assessment questionnaire individuals perceive each parameters/feature e.g. dryness of skin, hairs, skin colours, psychological attributes according to their own discretion that may entirely differ from others discretion.

(ii)-The questionnaires are of following types based on the classical text book that they followed:

a-Questionnaires which included all the descriptions available in all possible textbooks, especially Brihat Trayi and Laghu Trayi. b-Questionnaires that were based on only one classical Ayurvedic textbook ${ }^{20}$.

(iii)-The questionnaires are of following types based on the scoring system that was followed:

a-Absolute scoring, where, some fixed scores are allotted for each response/ character / trait that is present in an individual b-Graded scoring, where, the scoring varied from zero to five (or four in a few) based on the strength of agreement / disagreement with the question/ statement.

(iv)-Other Problems with different Questionnairesa-When the subject has to be considered as 'Ekadoshaja' and when 'Dvidoshaja' is not clear in most of the questionnaires. As every individual scores some score in all three Doshas, the criteria to be adopted for identifying the Dosha that is/ are to be eliminated is not clear.Similarly whether the most dominant Dosha is to be considered or the two most dominant Doshas are to be considered for designating one's Prakriti is also not clear. 
b-When we go through different treatises for the features of different Prakriti,we find that some peculiar feature is described only for one or two types of Prakriti but nothing has been elaborated in third type of Prakriti for same feature e.g.Vata Prakriti individual will be lean and thin and Kapha Prakriti individual will be having hefty,muscular and well built body but no description has been found for Pitta Prakriti individual for body built.With different questionnaires we find that medium body built has been assigned to Pitta Prakriti in an effort to make number of features or traits or questions equal for each Dosha although same is not described in classical texts.Such a type of incorporations may affect the real assessment of Prakriti. The number of parameters considered for Prakriti assessment may vary from doctor to doctor, which increase the assessment variability. Furthermore, the possibility of skipping important parameters and/or questions might lead to a different assessment $^{21}$.

c-When we are assigning Ekdoshaj/Dwidoshaj Prakriti what should be cut-off level for most dominant dosha in case of Ekdoshaj/Dwidoshaj prakriti is still not clear. In case of Dwidoshaj Prakriti what should be the minimum/maximum difference between most dominant and following Dosha is not clear.

d-It is often seen that while assigning Dual constitutional type, combination of two Dosha are considered same i.e. six combinations are converted into three combination types e.g.Vata-Kapha and Kapha-Vata are considered same but it may be possible that in Vata- Kapha, Vata may be $60 \%$ and Kapha may be $30 \%$,and in Kapha-Vata ,Kapha may be $60 \%$ and and Vata may be $30 \%$ so it will be difficult to consider both same.

e-When we assign dual constitutional type into six groups on the basis of dominant Dosha and following one then it is generally seen that number of individuals having Vata as most dominant Dosha are least in number in comparison to the individuals having Pitta and Kapha as most dominant Dosha. When we again divide this population on the basis of secondary Dosha then sometimes number of individuals is reduced up to such an extent that sometimes it is almost impossible to go for statistical calculation with such a small sample size.

f-We find that Proformas do not give proper weightage to Mental or Psychological attributes while Prakriti of an individual is defined into terms of both somatic and mental attributes i.e psychosomatic.

\section{CONCLUSION}

Conventional methods adopted for Prakriti examination are found inconsistent with huge inter and intra-rater inference variability. The main reason behind the poor reliability could be lack of a systematic objective methodology and a precise operational definition of the diagnostic methods.Combination of body shape, face pictures and matrices, voice recording,and a questionnaire might decrease the subjectivity of a physical assessment.Prakriti, for its tangible impacts upon decision making in Ayurvedic clinical practice, requires a thorough and foolproof method of examination.Evidence based decision making in Ayurveda should be welcomed as a mandatory move if Ayurveda is thought to be mainstreamed as a dependable and reproducible form of medical intervention.Additional research is needed to improve the reliability for these methods.Furthermore,future studies on reliability should be performed after establishing objective methodology and ensuring proper training.

\section{REFERENCES}

1. Shukla Ravi, Gehlot Sangeeta. Response of paschimottanasana and kapalabhati on CRP, resistin and RBS level in obese individuals. Int. J. Res. Ayurveda Pharm. Mar - Apr 2016;7(Suppl 2):160-164 http://dx.doi.org/ 10.7897/2277-4343.07279

2. Kang KR, Hwang SM, Park SJ,Chae H. A comparative study on traditional constitutional medicine in the world. Korean Journal of Orient. Medicine 2009; 15(3):35-43.

3. Sarsina PR, Alivia M, Guadagni P.Traditional, complementary and alternative medical systems and their contribution to personalisation, prediction and prevention in medicine-person-centred medicine. EPMA Journal 2012; $3(1): 15$

4. Hankey A. A test of the systems analysis underlying the scientific theory of Ayurveda's Tridosha. Journal of Altern. Complement. Med. 2005; 11: 385-90.

5. Kim JY,Pham DD,Koh BH. Comparison of Sasang constitutional medicine, traditional chinese medicine and Ayurveda. Evidence Based Complementary \& Alternative Medicine. 2011; 2011: 239659.

6. Patwardhan B, Warude D, Pushpangadan P, Bhatt N. Ayurveda and Traditional Chinese medicine: a comparative overview. Evid Based Complement Alternat Med. 2005; 2: 465-74.

7. Pine D. Introduction of Ayurveda to Chiropractic, Building a functional bridge, Proceedings of the Sacro Occipetalm Technique Research Conference, Nashville, Tennessee. 2011; p. 86-101.

8. Agarwal S, Negi S, Jha P, Singh PK, Stobdan T, Pasha MA, et al. EGLN1 involvement in high altitude adaptation revealed through genetic analysis of extreme constitution types defined in Ayurveda. Proceedings National Academy of Sciences U.S.A. 2010;107:18961-6.

9. Rizzo-Sierra CV. Ayurvedic genomics, Constitutional psychology and endocrinology: The missing connection. Journalof Altern. \& Complement. Med. 2011;17:465-8.

10. Prasher B, Negi S, Aggarwal S, Mandal AK, Sethi TP, Deshmukh SR, et al. Whole genome expression and biochemical correlates of extreme constitutional types defined in Ayurveda. Journal of Translational Medicine 2008; 6:48.

11. Mukerji M, Prasher B. Ayurgenomics: A new approach in personalized and preventive medicine Science \& Culture 2011; 77: 10-7.

12. Bijoya Chatterjee,Jigisha Pancholi. Prakriti-based medicine:A step towards personalized Medicine. AYU DOI: $10.4103 / 0974-8520.92539$

13. Kaptchuk TJ, Eisenberg DM. The persuasive appeal of alternative medicine, Ann. Intern. Medicine 1998;129:10615

14. Charaka, Charaka Samhita, edited by Shastri K, Vimana Sthana, Rogabhishagjiteeya Adhyaya-8/94, Chowkhamba Bharati Academy Publication,Varanasi, Reprint Edition 2001, 1983, p. 771.

15. Sushruta, Sushruta Samhita including the Dalhana Commentary, edited by Shastri A D Shareera Sthana.Garbhavyakaranam Shareera Adhyaya - 4/62, Chowkhamba Sanskrit Sansthan Publication, Varanasi, Edition-14, 2003. p. 37.

16. Charaka, Charaka Samhita, edited by Shastri K, Vimana Sthana, Rogabhishagiteeya Adhyaya-8/95, Chowkhamba Bharati Academy Publication, Varanasi, Reprint Edition 2001, 1983, p. 772.

17. Charaka, Charaka Samhita, edited by Shastri K, Indriya Sthana, Varnaswarendriya Adhyaya-1/5, Chowkhamba 
Bharati Academy Publication, Varanasi, Reprint Edition 2001, 1983, p. 968.

18. Kurande V, Bilgrau E, Waagepetersen R,Toft E, Prasad R. Interrater Reliability of Diagnostic Methods in Traditional Indian Ayurvedic Medicine. Hindawi Publishing Corporation Evidence-Based Complementary and Alternative Medicine Volume 2013 (2013), Article ID 658275

19. Kurande V, Waagepetersen R, Toft E, Prasad R.Reliability studies of diagnostic methods in Indian traditional Ayurveda medicine: An overview. Journal of Ayurveda and Integrative Medicine 2013; Volume: 4,Issue : 2 , Page : 67-76 .

20. Tripathi P, Patwardhan K, Singh G.The Basic Cardiovascular responses to postural changes, exercise and cold pressor test: Do they vary in accordance with the dual constitutional types of Ayurveda? Hindawi Publishing Corporation Evidence-Based Complementary and Alternative Medicine 2011; doi:10.1155//251850. Article ID 251850.

21. Lee S., Jang E., Lee J., Kim J. Y. Current researches on the methods of diagnosing sasang constitution: an overview. Evidence-based Complementary and Alternative Medicine 2009; vol. 6, no. 1, pp. 43-49.

\section{Cite this article as:}

Tripathi Piyush Kumar, Gehlot Sangeeta. Critical analysis of concept of Prakriti and challenges in its assessment: A review. Int. J. Res. Ayurveda Pharm. May - Jun 2016;7(3):1-4 http://dx.doi.org/10.7897/2277-4343.07399

Source of support: Nil, Conflict of interest: None Declared

Disclaimer: IJRAP is solely owned by Moksha Publishing House - A non-profit publishing house, dedicated to publish quality research, while every effort has been taken to verify the accuracy of the content published in our Journal. IJRAP cannot accept any responsibility or liability for the site content and articles published. The views expressed in articles by our contributing authors are not necessarily those of IJRAP editor or editorial board members. 